\title{
ViRuses In Marine PlankTonic SYSTEMS
}

By Jed A. Fuhrman and Curtis A. Suttle

\section{Introduction}

The last $10-15$ years have seen major changes in our views of marine planktonic food webs, primarily from the realization that prokaryotic microorganisms and small eukaryotes are responsible for a significant fraction, often $50 \%$ or more, of the primary production and heterotrophic consumption of organic matter in these systems (Williams, 1981; Azam et al., 1983: Stockner and Antia. 1986: Fuhrman, 1992). However, it has only been in the past few years that marine scientists have investigated the roles of viruses in ecological processes. Although this research area is only in its infancy, early results suggest that viruses may be important agents in the mortality of marine microorganisms and in controlling their genetic compositions. This paper will summarize the experiments and measurements that have led to this suggestion as well as the conceptual framework within which they are interpreted.

Viruses are fundamentally different from most other biological entities in that they have no metabolism of their own and must rely on a host organism for any energy-requiring process, including reproduction. In many cases the host-virus relationship is very specific, with the viruses infecting a single species or sometimes subspecies or genus. Because most organisms seem to be susceptible to viral infection, this suggests there are millions of different kinds of viruses. They are very small, usually from 20 to $250 \mathrm{~nm}$ in diameter (hence they would be defined by most chemical oceanographers as "dissolved organic matter"). They are composed of nucleic acid packaged in a protein coat, with some viruses having lipid present as well. The nucleic acid can be DNA or RNA, either of which can be single- or doublestranded. There are several morphologies, includ-

J.A. Fuhrman, Department of Biological Sciences, University of Southern California, Los Angeles, CA 90089-0371. USA. C.A. Suttle, Marine Science Institute. The University of Texas at Austin. PO Box 1267. Port Aransas, TX 78373-1267. [SA. ing regular structures such as icosahedrons (with or without a "tail"), filaments, and types with variable morphology types (Figs. 1 and 2).

There are three basic viral life cycles, all of which start with attachment of the virus to a specific site and injection of the viral nucleic acid into the host cell (Fig. 3). In the lytic cycle, this nucleic acid "commands" the cell to produce multiple viral progeny (often tens to hundreds) that are released into the environment when the host cell lyses (bursts). Also common among prokaryotes is a process called lysogeny, in which the injected nucleic acid can become integrated into the host's genome. This "provirus" is reproduced along with the host DNA for many generations until the survival of the host is threatened, at which time specific biochemical mechanisms can trigger the onset of the lytic cycle. Viruses capable of lysogeny are called "temperate," and they can be lysogenic in certain strains of hosts, and purely lytic in others. Many bacterial isolates have been found to be lysogens, which means that they harbor one or more proviruses that can be induced to become lytic. Among both prokaryotes and eukaryotes, "chronic infections" can also occur where viral progeny are produced and shed from the host via budding or extrusion of filaments, while host metabolism and reproduction proceed relatively unaltered. In metazoans viral infections are usually specific to certain tissues or organs.

\section{The Presence and Abundance of Marine Viruses}

\section{Viruses infecting specific hosts}

The existence of viruses in the marine environment has been known for many years (e.g., Kriss and Rukina, 1947: Spencer, 1955, 1960), although most of the early studies were concerned less with enumerating viruses than with characterizing isolates in terms of salinity and temperature effects, morphology, host range, etc. (e.g., Spencer, 1960; Hidaka, 1971; Hidaka and Fujimura, 1971; Zachary, 1976, 1978; Baross et al., 1978, see review by Børsheim, 1993). These studies focused
. . early results suggest that viruses may be important agents in the mortality of marine microorganisms . . 

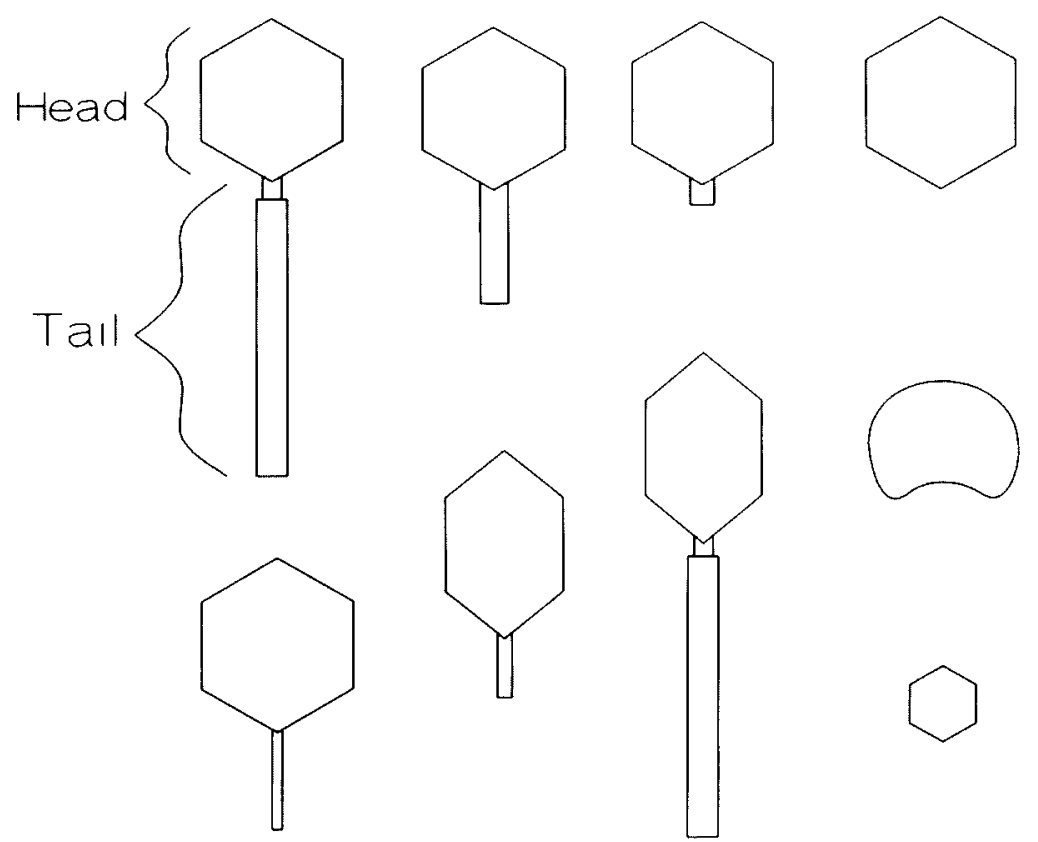

Fig. 1: General morphologies of viruses (primarily bacteriophages), modified from Ackermann and DuBow (1978). Another common term for the head is "capsid." Typical head diameters are 20-200 nm, although some larger ones are known. Of the types shown, the only ones readily recognized in electron micrographs from seawater are those with polyhedral heads (see Fig.2). Filamentous ones, which are very flexible and are represented by the long thin rectangle on the right, and irregularly shaped ones are not easily distinguished from other filaments or similar sized "blobs" in seawater.

The great variability of

specific virus abun-

dances probably largely

reflects the variability of

host abundances... . on viruses infecting bacteria (bacteriophages or phages). If such studies can be used as a guide, the potential for viral infection seems high, as $10-50 \%$ of marine bacteria isolates have been reported to be susceptible to infection by cultured phage (Hidaka, 1977). However, Moebus and Nattkemper (1983), who studied phage sensitivity of 1,382 bacterial isolates and found that many could be infected with culturable phages, suggested that this might be because bacteria that can be isolated from seawater may be particularly susceptible to such phages.

Evidence of viral infections in photosynthetic marine organisms began to accumulate in the 1970 s with a number of observations showing the presence of virus-like particles (VLPs) in cultures and natural assemblages of phytoplankton (e.g., Chapman and Lang, 1973; Pienaar, 1976; see also reviews by Dodds, 1979, 1983; Van Etten et al., 1991). These studies, however, provided no evidence that there were viruses in seawater that could infect and kill phytoplankton, although even earlier studies (e.g.. Safferman and Morris, 1963, 1967) had demonstrated the presence of viruses that infected freshwater cyanobacteria (prokaryotic phytoplankton). The first evidence of infective "phycoviruses" in seawater was provided by Mayer and Taylor (1979) who isolated a large polyhedral virus, $130-135 \mathrm{~nm}$ in diameter, that caused lysis of a widely distributed photosynthetic flagellate, Micromonas pusilla. They tested 35 different species from five classes of algae and found that the virus was specific for $M$. pusilla. Despite the potential ecological significance of their observations and indications that the virus could achieve high concentrations in seawater, research beyond initial characterization of the virus life cycle (Waters and Chan, 1982) was not pursued. It was not until more than a decade later that it was shown that viruses infecting representatives from a number of important groups of phytoplankton including cyanobacteria, diatoms, a prasinophyte, and a cryptophyte could be readily isolated from seawater (Suttle et al. 1990).

Concentrations of viruses which infect particular hosts can vary widely, ranging from less than a few viruses per liter of seawater to concentrations $>10^{8} \mathrm{~L}^{-1}$. For example, Spencer (1960) and Moebus $(1987,1992 \mathrm{~b})$ most often found abundances $<10^{4} \mathrm{~L}^{-1}$ for phages that infected marine bacterial cultures. However, in the Kiel Bight (a somewhat polluted embayment of the Baltic Sea), Ahrens (1971) found up to $3.7 \times 10^{7}$ phage $\mathrm{L}^{-1}$ that infected a strain of Agrobacterium stellatum, and Moebus (1992b) reported counts near Helgoland, Germany, sometimes as high as $1.5 \times 10^{7}$ phage $\mathrm{L}^{-1}$ infecting one host strain; the highest abundances tended to last only a few days. In the coastal waters of Texas the concentration of phages that infect two taxonomically uncharacterized marine bacteria (PWH3a and LMG1) varies temporally and spatially, and is different for the two hosts. For example, titers of viruses infecting PWH3a varied from $<0.7$ to $101 \mathrm{~L}^{-1}$; whereas, in the same sample viruses infecting LMG1 ranged between 12 and $3.97 \times 10^{5} \mathrm{~L}^{-1}$ (Suttle et al., 1991). The high densities were coincident with a toxic dinoflagellate bloom. In the coral reef environment near Key Largo, Florida, bacteriophages infecting cultured Vibrio species were also spatially variable, generally reaching highest concentrations $\left(>75 \mathrm{~L}^{-1}\right)$ in the nearshore and inshore environments where salinities were lowest (ca. 28-30 ppt) and decreasing offshore where salinities were $>34$ ppt (Paul et al., 1993). However, comparably high phage concentrations were found at one offshore station. Concentrations of viruses that infect photosynthetic plankton are also extremely variable. For instance, viruses that infect the photosynthetic flagellate Micromonas pusilla range in titer from $<20 \mathrm{~L}^{-1}$ in the central Gulf of Mexico to $4.6 \times 10^{6} \mathrm{~L}^{-1}$ in some coastal water samples (Cottrell and Suttle, 1991). The great variability of specific virus abundances probably largely reflects the variability of host abundances, because the viruses are dependent on hosts for reproduction.

Of viruses infecting specific hosts, those found in the highest known concentrations are cyanophages 


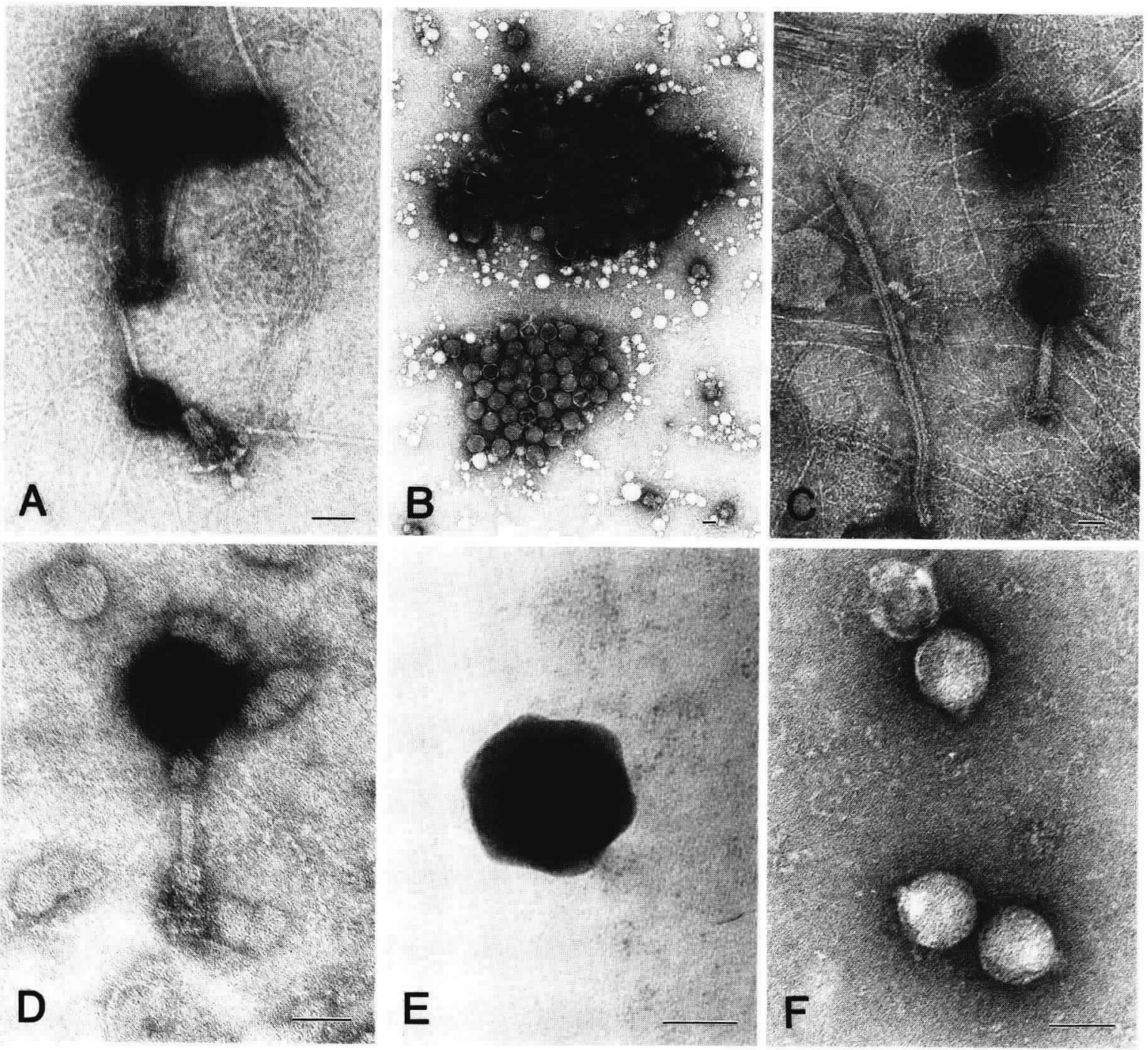

Fig. 2: Transmission electron micrographs showing the morphological diversity of marine viruses. A-C), Natural virus communities from the Gulf of Mexico; D and F), Cyanophages ( $S-P W M 4$ \& $S-P W P I)$, which infect strains of Synechococcus spp.; E) Virus (MPV-SPI), which infects the photosynthetic flagellate Micromonas pusilla. Scale bar equals $100 \mathrm{~nm}$.

(viruses that infect cyanobacteria) infecting the genus Synechococcus. This is of ecological significance because the genus Synechococcus is among the most important primary producers in the open sea, thought to account for a substantial portion of the carbon fixation in the world's oceans (Joint and Pomroy, 1983; Li et al., 1983). In coastal waters and along a transect in the nutrient-deplete waters of the western Gulf of Mexico cyanophages infecting a single Synechococcus strain occurred at concentrations ranging from $10^{3}$ $\mathrm{L}^{-1}$ to $>10^{8} \mathrm{~L}^{-1}$ (Suttle et al., 1993; Suttle and Chan, 1993). The concentration of viruses varied seasonally and was dependent upon the host strain of Synechococcus that was screened.

Viruses also infect members of the zooplankton. A number of viruses are known to infect microzooplankton, including rotifers (Comps et al.,
1991), and a virus has recently been isolated that infects a marine heterotrophic nanoflagellate (D.R. Garza and C.A. Suttle, unpublished observations). Because a large number of viruses are known to infect crustaceans in aquaculture, it seems likely that crustacean zooplankton would be susceptible to viral pathogens. For example, at least six fatal viral diseases of penaeid shrimp are recognized (Sindermann, 1990). Almost nothing is known about the abundance or ecological significance of viruses that infect zooplankton, and this remains a potentially fruitful area for research.

The large-scale distribution of marine bacteriophages infecting several cultured bacteria was studied by Moebus and Nattkemper (1981). They found that in the Atlantic between Europe and Bermuda, broad geographic patterns of host sensitivity were apparent, and phages isolated from widely sepa-
A

Imost nothing is known about the abundance or ecological significance of viruses that infect zooplankton . . . 


\section{VIRUS LIFE CYCLES}

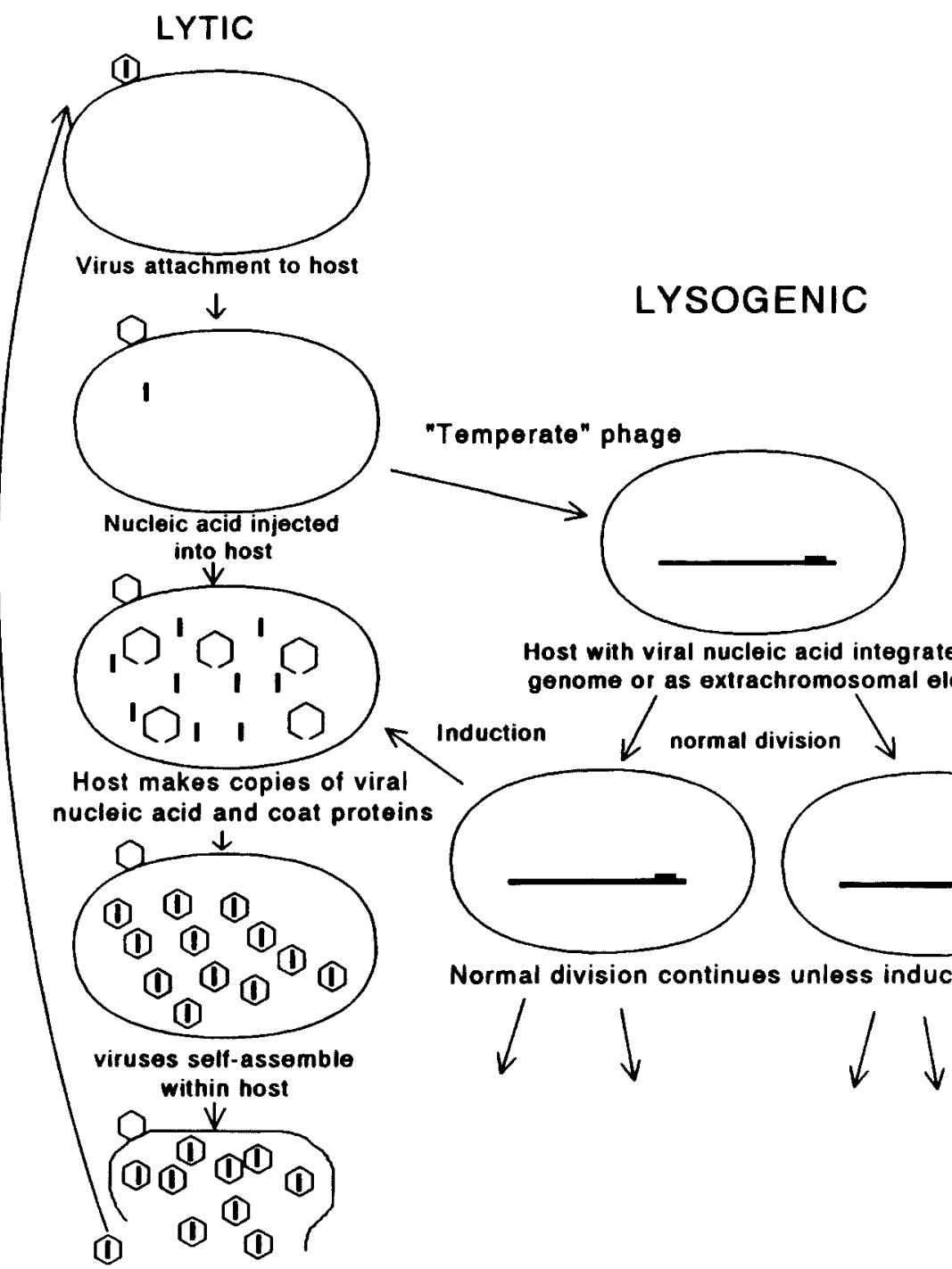

Host lyses to release progeny viruses

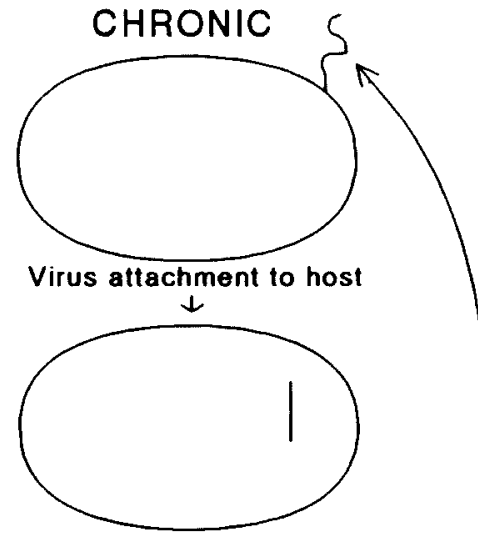

Viral nucleic acid injected

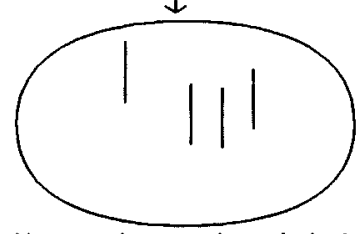

Host makes copies of viral nucleic acid and coat proteins

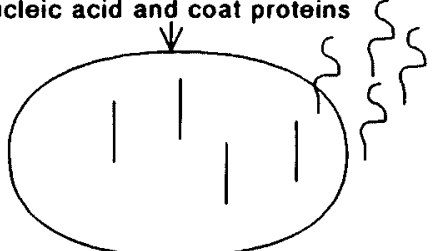

Host releases progeny viruses without lysing - by budding or extrusion

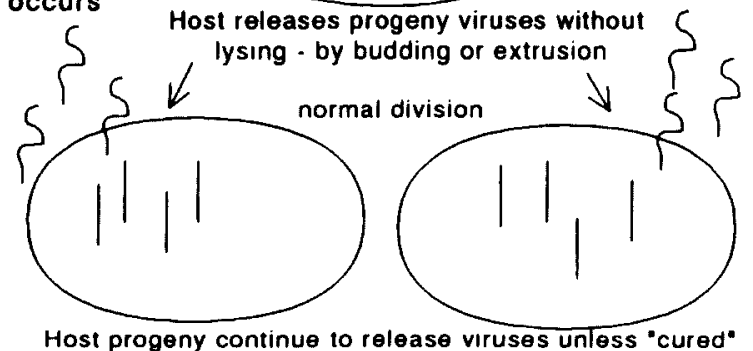

Fig. 3: General plan of the three basic virus life cycles, diagramming bacterial infection. To date, most of the observed and discussed effects of infection in the sea are associated with the lytic cycle (or the lytic part of the lysogenic cycle). Lysogeny is obviously of interest and is now beginning to be studied in marine samples, especially because a well-known induction factor is UV light, which is present in surface waters. Chronic infection, which has relatively subtle effects, has yet to be studied in marine samples.

rated geographic areas were able to cause lysis of certain hosts. Phycoviruses infecting some eukaryotic phytoplankton are also extremely widespread. Viruses infecting Micromonas pusilla have been found in every coastal seawater sample screened, including samples from the coasts of New York, Texas, California, and British Columbia (Cottrell and Suttle, 1991), as well as in the oligotrophic central Gulf of Mexico. Similarly, cyanophages infecting Synechococcus spp. have been found in every seawater sample of hundreds screened from the Gulf of Mexico (Suttle and Chan, 1993). They were found at all times of the year, at salinities ranging from $18-70 \mathrm{ppt}$ and $12-30.4^{\circ} \mathrm{C}$, and at depths to $97 \mathrm{~m}$ (Suttle and Chan, 1993; C.A. Suttle, unpublished observations). They were also found in a single seawater sample screened from coastal New York. Infectious cyanophages were distributed with the highest concentrations in nearshore waters coincident with the distribution of phycoerythrincontaining Synechococcus. In surface waters of the Gulf of Mexico, cyanophages infecting certain strains of Synechococcus are typically at least an order of magnitude or more abundant than the total concentration of Synechococcus spp. (Suttle and Chan, 1993). The numbers were also found to decrease rapidly below depths of $30 \mathrm{~m}$ (C.A. Suttle, unpublished observations). 


\section{Natural marine virus communities}

Perhaps not surprisingly, estimates of viral abundance in seawater based on the number of viruses infecting a specific host in culture greatly underestimate the total concentration of viruses determined by microscopy. This is because $>99 \%$ of bacteria in typical native heterotrophic bacterial communities are nonculturable on standard media (Ferguson et al., 1984; Lee and Fuhrman, 1991); hence, bacteria used as bioassay organisms are probably not representative of the natural microbial community. Additionally, even minor differences between host strains can sometimes affect susceptibility to phage infection (Ackermann and DuBow, 1987), resulting in a minimum estimate of phage abundance for a particular species. Furthermore. viruses that are noninfective can be counted by microscopy but not with a bioassay, which also must be borne in mind when interpreting and comparing results.

Transmission electron microscopy (TEM) has most often been the choice for viewing viruses directly because it affords resolution of up to a few nanometers, permitting visualization of the shape and morphological details of the viruses. Sieburth (1979) used TEM to observe viruses in seawater but did not provide concentration estimates. The first quantitative estimates of viral abundance in seawater were provided by Torrella and Morita (1979) who reported $>10^{4}$ viruses $\mathrm{mL}^{-1}$ in coastal Oregon waters. These were obvious underestimates because only viruses retained by $0.2 \mu \mathrm{m}$ pore size filters were counted. These authors suggested that the viruses were primarily bacteriophages, and that processes such as genetic transfer could occur in the sea via viral infection. Once again, these exciting observations were not pursued in a rigorous or systematic fashion by other investigators for several years.

It was not until the late 1980 s that direct counts of viral abundances in the range of $10^{\mathrm{h}} \mathrm{mL}^{-1}$ were reported by Sieburth et al. (1988) using epifluorescence microscopy to count virus-sized particles stained with a DNA-specific fluorochrome (DAPI), and by Proctor et al. (1988) using TEM. These were followed shortly by estimates ranging from $<10^{7}$ to $>10^{8} \mathrm{~mL}^{-1}$ for a variety of marine waters (Bergh et al., 1989; Proctor and Fuhrman, 1990), including the Gulf Stream and open ocean. Interestingly, new technology was not required for the "discovery" of high virus concentrations in seawater; rather, old methods (e.g., Sharp, 1949) were simply applied to a new problem.

Subsequently, high abundances of marine viruses were confirmed in many samples from several locations and depths, using a variety of methods (Børsheim et al., 1990; Bratbak et al., 1990; Suttle et al., 1990, Hara et al., 1991, Heldal and Bratbak, 1991; Paul et al., 1991; Bratbak et al., 1992b; Wommack et al., 1992; Cochlan et al.,
1993; Fuhrman et al., 1993; Paul et al., 1993, reviewed by Børsheim, 1993). Most of the recent counts have been typically $10^{6}$ to $10^{7} \mathrm{~mL}^{-1}$ in ocean surface waters, and up to $\sim 10^{8} \mathrm{~mL}^{-1}$ in the richest coastal waters, estuaries, and embayments. Virus abundances $>10^{5} \mathrm{~mL}^{-1}$ have even been reported for the Southern Ocean in winter, where phytoplankton and bacterial abundances are extremely low (Smith et al., 1993). Most counts have been done by TEM, but counts using epifluorescence microscopy yield similar results (Suttle et al., 1990; Hara et al., 1991; Proctor and Fuhrman, 1992; Fuhrman et al., 1993). However, counts by TEM have sometimes greatly exceeded those by epifluorescence (Paul et al., 1991). Methodological details (filter and stain types, prefiltration, optics of the microscope, detection by eye, film, or video) are probably critical. Counting methods are reviewed in detail elsewhere (Suttle, 1993).

Viral abundance typically parallels that of bacteria, with abundances decreasing from nearshore to offshore waters and from surface to deep waters; the number of viruses generally exceeds that of bacteria by $\sim 5$ - to 10-fold (Hara et al., 1991, Paul et al., 1991, 1993; Wommack et al., 1992, Cochlan et al., 1993). The strength of this relationship, as well as the fact that bacteria are by far the most abundant potential hosts, indirectly suggest that the majority of viruses infect bacteria (Paul et al., 1991; Cochlan et al., 1993). However, the data do not exclude the possibility that viruses infecting other organisms may be numerically and ecologically important members of marine viral communities. It is important to keep in mind that cyanophages (e.g., Suttle and Chan, 1993) and even some viruses that infect eukaryotic phytoplankton (Van Etten et al., 1991) can be morphologically indistinguishable from phages which infect heterotrophic bacteria. Consequently, it is premature to draw any firm conclusions about what kinds of viruses dominate natural systems.

\section{Diversity of Viral Communities}

The morphological diversity within natural marine virus communities is enormous (Fig. 2, see also size data reviewed by Børsheim, 1993), and some extremely large marine virus-like particles have been found with heads the size of small bacteria $(0.4 \mu \mathrm{m}$ ) and $2.5 \mu \mathrm{m}$-long tails (Bratbak et al., 1992a). This diversity suggests that they are also diverse in terms of the hosts that they infect. In fact, because there are $\sim 10^{7}$ viruses $\mathrm{mL}^{-1}$ in mesotrophic seawater, but generally only a few hundred viruses $\mathrm{mL}^{-1}$ or less infecting a particular host (with the exception of cyanophages), it has been suggested that the viruses in a given milliliter of seawater could infect $>10^{+}$different host species (Suttle et al., 1991)! However, this suggestion should be tempered by the possibilities that most of the virus particles in seawater are not
Viral abundance typi-

cally parallels that of

bacteria . . . 
infective (see below) or that the model virus-host systems that have been isolated are not representative of natural virus communities.

The genetic diversity of marine viruses is certainly greater than the observed morphological diversity. For example, a group of morphologically indistinguishable viruses that infect the photosynthetic flagellate Micromonas pusilla are genetically very different, even though some were isolated from the same water sample (Cottrell and Suttle, 1991).

\section{Dynamics of Viruses and Viral Communities}

Viruses are a dynamic component of marine systems. Rapid changes in viral abundance have been observed in microcosms filled with coastal seawater in which certain size classes of viruses increased exponentially at $0.4 \mathrm{~d}^{-1}$ for 5-7 d (Børsheim et al., 1990), and during a diatom bloom when viral abundance increased from $5 \times 10^{5}$ to $1.3 \times 10^{7} \mathrm{~mL}^{-1}$ at the bloom's peak before declining at a net rate of $0.33 \mathrm{~d}^{-1}$ (Bratbak et al., 1990). These authors suggested that the rapid increases may have resulted from induction by light of prophages within lysogenic bacteria (further discussed by Thingstad et al., 1993). Similarly, viral abundance changed as much as twofold in $24 \mathrm{~h}$ in 60-L enclosures of Norwegian coastal water (Heldal and Bratbak, 1991). Such dynamics indicate that viruses are being produced and destroyed at rapid but variable rates.

There has long been interest in determining loss rates and mechanisms of viral decay in seawater. Potential decay mechanisms include extracellular digestion by enzymes (free in the water or on the surfaces of cells), damage from UV or visible light, adsorption onto living or nonliving particles and possible subsequent ingestion of the particle by grazers, unsuccessful infection of a host, direct ingestion by protists, and attack by chemicals other than enzymes. Most viral decay studies have focused on the decay of infectivity of human pathogens and coliphages (phages infecting human intestinal bacteria). Data from such studies suggest that infectivity decays quickly with $90 \%$ of the infectious bacteriophage isolates typically destroyed in 1-10 days (Kapuscinski and Mitchell, 1980); average daily decay rates are $\sim 20-90 \%$ per day. The data from these earlier studies suggested that decay is primarily biologically mediated, although chemical effects and effects from solar radiation were also implicated (e.g., Mitchell, 1971; Shuval et al., 1971; Berry and Noton, 1976). In addition, colloids and particulate material were shown to adsorb and re-release coliphages in seawater, effectively slowing decay (Bitton and Mitchell, 1974; Bitton, 1975; Gerba and Schaiberger, 1975; Smith et al., 1978). These studies identified mechanisms that could be important in regulating the abundance of marine viruses.
Among the few early studies on decay rates of native viruses in aquatic environments were those of Zachary (1976), who found that phages infecting the estuarine bacterium Vibrio natriegens decayed relatively slowly in estuarine water. One isolate (nt-6) decayed at 7-18\% per day for $60 \mathrm{~d}$; whereas another (nt-1) decayed at $18 \%$ per day for the first 10 days, but only $0.3-0.7 \%$ per day for the next 50 days. This change in the decay rate was possibly because the phage found a refuge from the inactivation factor(s) or the inactivation factor was reduced considerably. In contrast, the phages showed no inactivation over $\geq 60 \mathrm{~d}$ in autoclaved or filter-sterilized estuarine water, or sterile saline media. The data suggested that inactivation was heat-labile and particle-associated (e.g., microbial), and that different phages can decay at different rates in the same water. More recently, Moebus (1992a) found comparable rates (typical inactivation rates of $10-30 \%$ per day) and high variability in a study of survivability of nine cultured phages suspended in water sampled from near Helgoland in the North Sea. He concluded that indigenous bacteria have the predominant role in phage inactivation.

Given the potential importance of attachment to particles as a mechanism for removal of viruses, Murray and Jackson (1992) constructed a model investigating the potential effect of single-celled organisms and other particulates on the removal rates of viruses from seawater. They concluded that there was a fairly close relationship between the abundance of bacteria and the removal rates of viruses in seawater. They postulated that virus attachment to nonhost organisms is potentially a major source of virus removal in seawater.

Recently, decay of infectivity of three cultured marine phages containing double stranded DNA was estimated from Texas coastal water at 22 to $67 \%$ per day in the dark, with different viruses decaying at different rates (Suttle et al., 1992; Suttle and Chen, 1992). Again, interaction with heat labile particles was responsible for much of the decay because viruses did not decay or decayed very slowly in autoclaved, $0.2-\mu \mathrm{m}$-filtered or ultracentrifuged seawater. These interactions could include passive adsorption in addition to enzymatic microbial processes. Cyanide, an inhibitor of respiration, caused rates to decrease by $\sim 60 \%$, indicating that energy-requiring biological processes were responsible for some of the decay. As decay rates were greatly reduced in 0.8 - or $1.0-\mu \mathrm{m}$ filtered seawater, whereas bacteria numbers were not, it suggested that the largest bacteria (removed by the filtration) or other organisms were responsible for some of the decay, or that filtration inhibited bacteria-mediated decay. Decay rates were also accelerated when viruses were added to cultures of heterotrophic nanoflagellates, corresponding to 3.3 viruses inactivated flagellate ${ }^{-1} h^{-1}$. These 
results closely agree with observations that phagotrophic nanoflagellates ingest and digest fluorescently labelled marine viruses (Gonzalez and Suttle, 1993). In the absence of solar radiation, a major factor responsible for viral decay was probably attachment to fragile, heat-labile aggregates. However, in the presence of full sunlight decay rates were greatly accelerated $\left(0.4-0.8 \mathrm{~h}^{-1}\right)$. Even when UV-B was blocked, rates were as high as $0.17 \mathrm{~h}^{-1}$.

The data described above were the basis of a model that partitioned viral decay among different mechanisms in the top $10 \mathrm{~m}$ of a hypothetical coastal water column (Suttle and Chen, 1992). The average decay rate of infectivity attributable to micrometer-scale particles (adsorption plus microbially mediated decay) was $0.41 \mathrm{~d}^{-1}$, and that resulting from solar radiation was $0.38 \mathrm{~d}^{-1}$. At typical viral and flagellate abundances, grazing by nanoflagellates was of minor importance, accounting for a loss rate of only $0.002 \mathrm{~d}^{-1}$. Extrapolating to a $200 \mathrm{~m}$ oceanic water column, light could be the major factor causing decay of viral infectivity. Furthermore, as sunlight destroys infectivity approximately 15 times more rapidly than it does virus particles (Suttle et al., 1993), a large proportion of the viruses in seawater may not be infective. This should also lead to a strong diel signal in the concentration of infectious viruses. Even in unlit waters many of the viruses may be noninfective as viral inactivation (by all mechanisms) likely occurs faster than removal.

The model presented by Suttle and Chen (1992) was based on three randomly selected marine virus isolates, which showed a range of sensitivities to solar radiation. Other marine viruses are less susceptible to sunlight. We recently conducted tests on the same day at Los Angeles, California, and Port Aransas, Texas, using local seawater and ambient sunlight to test the effect of solar radiation on a double-stranded DNA bacteriophage isolated from the North Sea (H40/1; Frank and Moebus, 1987). Photosynthetically active irradiance at Port Aransas during the $7-\mathrm{h}$ incubation averaged $1,172 \mu \mathrm{mol}$ photons $\mathrm{m}^{-2} \mathrm{~s}^{-1}$. Decay rates of $\mathrm{H} 40 / 1$ were relatively slow in full sunlight, ranging from $0.05-0.11 \mathrm{~h}^{-1}$ at both locations. Another phage isolated from the North Sea (H85/1) showed similar decay rates in Los Angeles, but in contrast, one of the viruses used in previous sunlight decay experiments (PWH3a-P1) decayed nearly three times as fast $\left(0.32 \mathrm{~h}^{-1}\right)$ at Port Aransas. Thus the susceptibility of infectivity to sunlight is virus dependent, and the model described above may overestimate or underestimate the actual decay rates experienced by individual components of natural marine viral communities when they are exposed to solar radiation. The reasons for the variation in light susceptibility are unknown, but may be related to differences in the DNA repair mechanisms of the hosts (note that free viruses have no metabolism so they cannot repair themselves), or to the ability of virus-encoded nucleic acid polymerases to function on radiation-damaged DNA.

The observed rapid viral dynamics imply actual disappearance of the viruses, not just loss of infectivity. Heldal and Bratbak (1991) estimated disappearance rates in field samples by attempting to stop virus production with cyanide while determining removal rates of the remaining viruses from TEM counts. Cyanide will stop virus production by inhibiting host respiration, without directly affecting enzymes (e.g., proteases or nucleases) that might destroy viruses. In contrast to culture results (see above), cyanide was not found to affect viral decay rates in the sample that was tested. Using this approach they measured extremely rapid decay rates of 0.3 to $1.1 \mathrm{~h}^{-1}$ for slightly over $60 \%$ of the viral population during the first few hours. However, $\sim 40 \%$ of the viruses were relatively persistent after this initial rapid decline and disappeared at much slower rates $\left(<0.05 \mathrm{~h}^{-1}\right)$.

An important contribution of these studies was the idea that production rates can be estimated by comparing loss rates in cyanide treated and untreated samples (where production is continuing); the difference between the two represents virus production. They estimated the total bacterial lysis rate from phage infection by assuming that the virus community size is maintained at a constant level (as they observed), each lysis event releases 50-100 progeny viruses ("burst size" estimated in their study), and $50 \%$ of the viral population decays at the faster measured rates. This model yielded estimates of $2-24 \%$ of the bacterial population being lysed per hour, thus requiring bacterial growth rates of $0.4-6 \mathrm{~d}^{-1}$ to balance virus-induced mortality. The higher end of this range is much greater than most growth rate estimates for marine bacteria in natural waters $\left(0.5-2 \mathrm{~d}^{-1}\right)$, so these results have met with some skepticism. More recently, Bratbak et al. (1992b) found slower decay rates $\left(0.3-0.4 \mathrm{~h}^{-1}\right)$ for $\sim 30 \%$ of the virus population (the rest decaying more slowly) in Danish coastal waters. Using an estimate of 100 for burst size, this corresponded to a more believable $72 \%$ per day bacterial mortality. Yet, the measured bacterial production rate (from thymidine incorporation) was capable of supporting only one sixth of the estimated viral production rate. Moreover, these authors estimated that grazing by protists consumed bacteria about twice as fast as the estimated bacterial production rate. Obviously, the rate measurements cannot all be correct. Although the use of a higher thymidine conversion factor would help, factors in the commonly accepted range would not be adequate to account for the sevenfold increase in production that would be necessary to balance all the measurements. 
It is also difficult to reconcile some of the very fast estimates of viral decay based on particle disappearance with the much slower rates based on decay of infectivity, because decreases in infectivity should provide more conservative estimates of viral decay than the disappearance of viruses. It is possible that the cultured viruses in infectivity studies are not representative of those in natural communities. The following are alternative explanations: 1) very rapid decay rates may be characteristic of certain water types, 2) the cyanide protocol overestimates virus disappearance rates, or 3 ) decay rates of infectivity have been inhibited in the other studies. Recent cyanide experiments in California waters have sometimes yielded the unexpected (and uninterpretable) result of a significant increase in viral abundance after the addition of cyanide, indicating that unknown processes can occur in these experiments and caution must be used in their interpretation (J.A. Fuhrman, R.T. Wilcox and R.M. Noble, unpublished observations). Clearly, studies need to be done in which losses of virus particles and decreases in infectivity are monitored simultaneously.

A recent contribution that may help settle some of this controversy is an approach for directly measuring virus production in natural samples using radioactive phosphate or thymidine (Steward et al., 1993a,b). The isotopes are incorporated into viral nucleic acids, which are purified by a combination of physical separation and chemical or enzymatic treatments. By this method they found that virus production had a strong onshore-offshore gradient in the waters off Southern California. Production rates ranged from $<1 \times 10^{8}$ (undetectable) to $2.3 \times 10^{11}$ viruses $\mathrm{L}^{-1} \mathrm{~d}^{-1}$, with values highest in a coastal lagoon and lowest in offshore oligotrophic waters. The values are conservative because they do not account for losses during filtration or purification, which can be $>50 \%$.

\section{Viruses as a Cause of Microbial Mortality}

It is important to understand the mechanisms responsible for the mortality of marine bacteria and phytoplankton, as different routes of microbial mortality yield different pathways of organic matter flow and oxidation in the ecosystem (discussed below). Traditionally, flagellates and ciliates have been regarded as the only important agents of bacterial loss (reviewed by McManus and Fuhrman, 1988, and Pace, 1988); however, attempts to budget bacterial production and removal by protozoan grazers have often led to imbalances, suggestive of unknown mechanisms for the loss of bacteria (Servais et al., 1985; McManus and Fuhrman, 1988; Pace, 1988; Sherr et al., 1989).

Calculations of extremely high viral loss rates imply that high rates of bacterial mortality due to viral lysis must occur to support viral production (Heldal and Bratbak, 1991; Bratbak et al., 1992b, see discussion above). In addition, Suttle and Chen (1992) estimated that $4-13 \%$ of the bacterial community would have to be infected daily to support the observed viral decay rates. If bacteria in this area typically double about once per day, and if it is assumed that half of the bacteria are removed each day to maintain steady state, then viruses are responsible for $8-26 \%$ of the bacterial mortality.

Other evidence that viruses are important agents of mortality for bacteria and phytoplankton was obtained by adding virus-sized material, concentrated from seawater by ultrafiltration, to seawater samples, and documenting the effects on bacteria and phytoplankton communities. Significant declines in bacteria abundances (Proctor et al., 1988; Proctor and Fuhrman, 1992) and phytoplankton photosynthetic rates and biomass (Suttle et al., 1990; Suttle, 1992; Peduzzi and Weinbauer, 1993) occurred in samples exposed to these concentrates. The effect was eliminated if the concentrates were heat-treated before addition. Photosynthetic rates declined within minutes of adding the concentrates and were reduced by as much as $78 \%$. In fact, as little as a $20 \%$ increase in the 2-200 $\mathrm{nm}$ size fraction reduced photosynthetic rates by as much as $50 \%$. Microautoradiography indicated that only a subset of the phytoplankton community was affected and that phytoplankton $>3 \mu \mathrm{m}$ were inhibited the most. Note that the rapid response of photosynthesis cannot be from cell lysis, which probably occurs several hours after infection, and more likely represents regulation of cellular processes. Moreover, only a subset of the phytoplankton community was affected and photosynthetic biomass increased after a lag of $>1 \mathrm{~d}$ (Suttle, 1992; Peduzzi and Weinbauer, 1993). Although these studies indicated that the viral size fraction is strongly bioactive, the possibility cannot be dismissed that other substances (e.g., proteins) were concentrated by the procedures, and contributed to the effect.

Independent documentation of the importance of viruses was obtained from observing thin sections of natural plankton communities with TEM (Proctor and Fuhrman, 1990). Culture studies have shown that assembled (mature) phage typically appear at the final stage of the infection cycle; hence the proportion of infected cells can be estimated from the proportion of bacteria and cyanobacteria containing mature phage. In rich coastal, as well as oligotrophic offshore Atlantic environments, $\sim 1-4 \%$ of the bacteria and $1-3 \%$ of the cyanobacteria were visibly infected ( 3 or more phage per cell). These values were converted to mortality estimates using a three-part steadystate model. The first model component was that intracellular mature phage are only visible for about the last $10 \%$ of the infection cycle (from limited literature data); hence, the percent of visibly infected cells must be multiplied by about 10 
to estimate the total infected cells. Second. literature data indicated that the time between cell infection and lysis (latent period) is approximately the same as the generation time of the uninfected host grown in the same medium. Thus an infected cell is likely to die within a generation. Third, at steady state, each cell division results in one cell that will live and one that will die within a generation time (on average, to maintain steady state), so any factor that leads to the death of $50 \%$ of the cells in a generation is responsible for $100 \%$ of the mortality. This model suggested that one must multiply the percent of cells visibly infected by a "conversion factor" of 20 to estimate the percent of total mortality due to viral infection. It was concluded that as much as $30 \%$ of the total cyanobacterial mortality (from all causes) and $60 \%$ of the bacterial mortality could be due to lysis by phage. These estimates were a first approximation based on an uncertain conversion factor, and do not take into account the possibility that an infected bacterium may be eaten by a protist before the cell lyses.

These studies were extended to microorganisms in sinking particulate material collected from sediment traps at $30-400 \mathrm{~m}$ in the North Pacific (Proctor and Fuhrman, 1991). Viruses were common in this material and appeared aggregated. The fraction of cells containing mature phage was $0.7-3.7 \%$. The model was further refined for this study, and approximate lower and upper bounds were applied (still from limited literature data). The conclusion was that $2-37 \%$ of the cells in the sedimenting matter were likely to be killed by lysis.

Recently, the mortality model parameters were investigated in culture using two species of phageinfected heterotrophic marine bacteria (Proctor, 1991; Proctor et al. 1993). Almost all of the visible intracellular phage accumulated within the last $25 \%$ of the infection cycle, with most appearing within the last $10 \%$. Also, the averaged latent periods were very close to the generation times of uninfected hosts, but there was considerable variation around the mean. This basically confirmed the earlier interpretation and implied that the best current estimate for the "conversion factor" is between 10 and 20 , assuming that these laboratory model systems are representative of native marine phages. The field results thus indicate that perhaps $6-60 \%$ or more of the total bacterial mortality is due to viral infection. It should be noted that the same factor probably does not apply to cyanobacteria. Padan and Shilo (1973) and Leach et al. (1980) indicate that mature intracellular cyanophage can become abundant about halfway through the infection cycle, suggesting a conversion factor of about 4 . Thus given that only $\sim 1-3 \%$ of the native population appear infected (Proctor and Fuhrman, 1990), viruses may account for only $5-10 \%$ of the mortality of cyanobacteria.
A similarly low percentage has been calculated by J.B. Waterbury (unpublished observations), based on abundances and diffusion rates of cyanobacteria and cyanophages.

Another method that has been used to estimate the fraction of bacteria containing mature viruses has been to treat samples with streptomycin to lyse infected cells and release the viruses, which are observed by TEM (Heldal and Bratbak, 1991; Bratbak et al., 1992b). These authors report that the percent of bacterial cells containing mature phage particles was $8-14 \%$ in coastal Norwegian waters, and $12-29 \%$ in coastal Danish waters, with the latter showing a diel variation with lowest values near midnight and highest in afternoon. These percentages are much higher than estimated from thin sections by Proctor and Fuhrman (1990), and a conversion factor of 10-20 to estimate the percentage of bacterial mortality from the percentage of infected cells cannot be applied to these data. It is important to realize that the 10-20 conversion factor is empirical and applies only to thin sections, so this conversion would not be expected to apply to other means of observing infection. The total number of cells with mature phage will be higher than that observed in thin sections because thin sections observe only a portion of each cell, and the viruses can be located elsewhere in the cell. Also, Proctor and Fuhrman (1990) counted only cells with at least three visible mature viruses per section (to indicate the cell was in a late stage of infection), and many cells had fewer apparent viruses. While there are no estimates of mortality from the streptomycin method, the observation that a minimum of $8-29 \%$ of the bacteria were infected by viruses suggests that viruses have a significant impact on these systems.

The virus production data from Steward et al. (1993b) suggest mortality from viral infection is likely to be most important in coastal embayments as opposed to open ocean waters. As with the Heldal and Bratbak approach, it is necessary to know the burst size to estimate mortality rates from virus production measurements. Steward et al. used a large range of burst sizes (10-300), because of uncertainty with this number (the lowest burst sizes lead to the highest mortality estimates). The estimated fraction of bacterial mortality attributable to viruses was $25-740 \%$ in Peñasquitos Lagoon near San Diego, 12-372\% in Mission Bay, and $1-40 \%$ in offshore and nearshore Pacific Ocean samples. Estimates from Pacific Ocean samples overlap with those of Proctor and Fuhrman (1990). but the range is too large to say that there is "agreement."

\section{Effects on the Diversity of Microbial Communities}

One of the most important roles of viruses in planktonic communities is likely the maintenance
. . mortality from

viral infection is likely

to be most important

in coastal embay-

ments . . . 
viral infection is

potentially one of the

most important mech-

anisms maintaining

diversity. of diversity. More than $30 \mathrm{y}$ ago G.E. Hutchinson (1961) focused attention on a question that had plagued ecologists for years. Why do so many species of phytoplankton with similar resource requirements coexist in relatively homogeneous bodies of water, when theory would predict that a few species should be competitively dominant? Although the question was posed for phytoplankton, given our recent appreciation of the diversity of aquatic bacteria and protozoa it is appropriate to extend the question to these groups. Obviously, many factors contribute to the maintenance of community diversity including patchiness, nonsteady state conditions, selective predation, differences in the relative amounts of resources required, allelopathy, etc., but viral infection is potentially one of the most important mechanisms maintaining diversity (Suttle et al., 1990, 1992; Fuhrman, 1992; Thingstad et al., 1993). The rate at which a viral infection will spread is very dependent on the frequency with which viral particles will encounter a suitable host. Since infective viruses may have a relatively short residence time in seawater (see above) rapid propagation of a viral infection will occur best at relatively high host densities $\left(>10^{4}\right.$ host cells $\mathrm{mL}^{-1}$, Wiggins and Alexander, 1985). Still, infections can propagate slowly with host and phage densities of even 10 $\mathrm{mL}^{-1}$ (Kokjohn et al. 1991). Although the variety of hosts for marine viruses can be complex, viruses infecting marine bacteria and phytoplankton typically infect members of a single species or genus (e.g., Mayer and Taylor, 1979; Suttle and Chan, 1993). Consequently, even in the presence of very low viral titers, a high concentration of a susceptible host will lead to rapid viral propagation and lysis of the host population. The host is able to survive because there are invariably some cells present that are resistant to infection by the viral pathogen, and the extent of host survival will depend on their genetic diversity, as well as the abilities of the viruses to co-adapt (see review by Lenski, 1988). The result is that species that would otherwise be the competitive dominants may be kept in check by the presence of viral pathogens. Rapid propagation of viral infections when host densities are high may be the prime reason why planktonic communities are not dominated by a few species in nature.

Until recently, there has been little direct evidence for the termination of phytoplankton blooms by viruses in nature, although reports of bloom lysis (e.g., Gieskes and Elbrachter, 1986) and difficulties in balancing rates of primary productivity with loss rates for phytoplankton (e.g., Walsh, 1983) suggested that the process may be important. In contrast, Sieburth et al. (1988) suggested that even though virus-infected cells were visible throughout a bloom of the small chrysophyte Aureococcus anophagefferens, the bloom declined only after significant numbers of phagotrophic protists developed. They suggested that the viruses primarily influenced the genetic structure of the algal community (species and/or strain composition) rather than its size. A similar conclusion was reached by J.B. Waterbury (unpublished observations) regarding the marine cyanobacterium Synechococcus, and this generally follows the conclusions of Lenski (1988) based on extensive work with bacterial cultures. However, the most convincing evidence that viruses may terminate phytoplankton blooms comes from mesocosm studies in which the collapse of Emiliania huxleyi blooms was associated with the appearance of large polyhedral virus-like particles inside the cells and high concentrations of morphologically similar particles in the surrounding seawater (Dundas et al., 1992; Bratbak et al., 1993). It seems likely that although viruses may not be responsible for the termination of all or even most algal blooms, they play important roles in regulating phytoplankton species compositions and dynamics.

\section{Viruses and Organic Matter Cycling}

From a food web point of view, the fate of viral "biomass" is important. Individual infected cells lyse and release many viruses plus extensive cell debris. In a long-term, near-steady state situation, one would expect that an average of only one virus from each burst survives to infect another host successfully; otherwise, the virus abundance would explode or decline, neither of which seems to have happened for the group as a whole (this is for virulent infections; with lysogeny, even fewer viruses probably survive to infect a new host, because these types have an alternate survival strategy). Bratbak et al. (1990), Proctor and Fuhrman (1991), and Fuhrman (1992) present food web models that describe the effects of virus-caused mortality on the microbial food web. These have generally assumed that the cell debris from lysis and the material in released viruses return to "feed" the bacteria, in a closed loop that essentially oxidizes $\mathrm{C}$ and regenerates $\mathrm{N}$ and $\mathrm{P}$. A quantitative steady-state model presented by Fuhrman (1992) compared two microbial systems, one having all bacterial mortality from protistan grazing, and the other having $50 \%$ of the mortality from viruses and $50 \%$ from protists. The material released from lysed bacteria was assumed to cycle back to the bacteria as dissolved organic matter (DOM). The inclusion of viruses caused a $27 \%$ increase in both bacterial secondary production and bacterial respiration, a 37\% loss in the export of bacterial carbon to nanozooplankton grazers, a $25 \%$ loss in nanozooplankton secondary production, a $13 \%$ loss in microzooplankton production, and a $7 \%$ loss in macrozooplankton production. Thus the viruses caused a shift in food web activity (most notably, production and respiration) from larger organisms to bacteria, with the some- 
what unexpected conclusion that even in the absence of increased primary production, the presence of active viruses can lead to significant increases in bacterial production and respiration rates. However, these increases were accompanied by less rather than more carbon transfer to higher trophic levels. Modification of the model to include infection of primary producers (10\% of phytoplankton mortality), and consumption of viruses by nanozooplankton (13\% of virus production) increased bacterial production and respiration rates even more (33\% above the level without viruses), while at the same time slightly moderating the decline in nanozooplankton production (20\% loss instead of 25\%; J.A. Fuhrman, unpublished observations).

The effect of viruses on carbon and nutrient flow has particular bearing on the question of whether bacteria are a "link or sink" in the food web. When viruses are important agents of microbial mortality, repeated cycling of organic matter in the bacterial-viral loop (i.e., organic matter flows from bacteria to viruses to DOM to bacteria repeatedly, with bacterial respiratory losses along the way) causes the bacteria to be efficient sinks for $\mathrm{C}$ and regenerators of inorganic $\mathrm{N}$ and $\mathrm{P}$, even when they have a high production rate and growth efficiency. Variations in the relative significance of viruses may help explain why Ducklow et al. (1986) found the bacteria to be a sink while Sherr et al. (1987) indicated they can be more of a link.

An additional effect of viruses on nutrient cycling involves their roles in marine aggregates, which are thought to be major agents of transport of matter to the deep sea. As stated above, Proctor and Fuhrman (1991) noted significant viral infection of organisms in material collected from sediment traps. These authors described potential viral roles as follows: 1) viruses may act as nuclei for formation of aggregates, 2) some materials, such as nucleic acids and other polymers, released by viral cell lysis can act as "glues" to hold aggregates together. 3) they can cause release of DOM from aggregates as cells within are lysed, and 4) bacterial defenses against viral attack, such as release of proteases and nucleases, may rapidly digest aggregates, releasing more DOM and breaking up the aggregates (cf., Smith et al. 1992). Empirical evidence of the potential importance of viruses in marine aggregate formation can be found in recent work by Peduzzi and Weinbauer (1993) in which the addition of concentrated natural virus communities was found to stimulate the formation of algal flocs (marine snow).

Clearly, we are only just beginning to appreciate the importance of natural marine virus communities to nutrient and energy cycling, to the control of species diversity, and as vectors of genetic material in the marine environment. As we collect more data we will achieve a more quantitative understanding of the significance of viruses to planktonic communities and on the large scale flow of carbon, energy, and nutrients, which will allow us to incorporate viruses and viral-mediated processes into quantitative marine ecosystem models.

\section{Acknowledgments}

The authors thank W. Cochlan, G. Steward, F. Azam, J. Wikner, and D. Smith for sharing unpublished results, and K. Moebus for supplying bacteriophage isolates from the North Sea. R.T. Noble, R. Wilcox, and D.R. Garza were responsible for the virus survival experiments. A.M. Chan and M.T. Cottrell supplied the electron micrographs. J.B. Cottner and two anonymous reviewers made useful suggestions.

\section{References}

Ackermann, H.-W. and M.S. DuBow, 1987: Viruses of Prokaryotes. In: General Properties of Bacteriophages, vol. 1, CRC Press, Boca Raton, Florida, 202 pp.

Ahrens, R.. 1971: Untersuchungen zur verbreitung von phagen der gattung agrobacterium in der ostsee. Kiel. Meeresforsch., 27, 102-112.

Azam, F., T. Fenchel, J.G. Gray, L.A. Meyer-Reil and T. Thingstad, 1983: The ecological role of water-column microbes in the sea. Mar. Ecol. Prog. Ser., 10 , 257-263.

Baross, J., J. Liston and R.Y. Morita, 1978: Incidence of Vibrio parahaemolyticus bacteriophages and other Vibrio bacteriophages in marine samples. Appl. Environ. Microbiol., 36, 492-499.

Bergh, Ø., K.Y. Børsheim. G. Bratbak and M. Heldal, 1989: High abundance of viruses found in aquatic environments. Nature, 340, 467-468.

Berry, S.A. and B.G. Noton, 1976: Survival of bacteriophages in seawater. Water Res., 10, 323-327.

Bitton, G., 1975: Adsorption of viruses onto surfaces in soil and water. Water Res., 9. 473-484.

Bitton, G. and R. Mitchell, 1974: Effect of colloids on the survival of bacteriophages in seawater. Water Res., 8 . 227-229.

Børsheim, K. Y., 1993: Native marine bacteriophages. FEMS Microbiol. Ecol., 102, 141-159.

, G. Bratbak and H. Heldal, 1990: Enumeration and biomass estimation of planktonic bacteria and viruses by transmission electron microscopy. Appl. Environ. Microbiol, 56, 352-366.

Bratbak, G., J.K. Egge and M. Heldal, 1993: Viral mortality of the marine alga Emiliania huxleyi (Haptophyceae) and termination of algal blooms. Mar. Ecol. Prog. Ser., 93, $39-48$

O.H. Haslund. M. Heldal, A. Næss and T. Røeggen, 1992a: Giant marine viruses? Mar. Ecol. Prog. Ser., 85 , 201-202.

, M. Heldal, S. Norland and T.F. Thingstad, 1990: Viruses as partners in spring bloom microbial trophodynamics. Appl. Environ. Microbiol., 56, 1400-1405.

. M. Heldal, T.F. Thingstad, B. Riemann and O.H. Haslund, 1992b: Incorporation of viruses into the budget of microbial C-transfer. Mar. Ecol. Prog. Ser.. 83, $273-280$.

Chapman, R.L. and N.J. Lang, 1973: Virus-like particles and nuclear inclusions in the red alga Porphyridium purpurem (Bory) Drew et Ross. J. Phycol., 9, 117-122.

Cochlan, W.P., J. Wikner, G.F. Stewart. D.C. Smith and F. Azam, 1993: Spatial distribution of viruses, bacteria and chlorophyll a in neritic, oceanic and estuarine environments. Mar. Ecol. Prog. Ser., 92, 77-87.

Comps, M., B. Menu. G. Breuil and J.R. Bonami, 1991: Viral
... repeated cycling

of organic matter in

the bacterial-viral loop

... causes the bac-

teria to be efficient

sinks for $C$... 
infection associated with rotifer mortalities in mass culture. Aquaculture 93, 1-7.

Cottrell. M.T. and C.A. Suttle, 1991: Wide-spread occurrence and clonal variation in viruses which cause lysis of a cosmopolitan, eukaryotic marine phytoplankter, $\mathrm{Mi}$ cromonas pusilla. Mar. Ecol. Prog. Ser., 78, 1-9.

Dodds, J.A., 1979: Viruses of marine algae. Experentia 35, $440-442$.

1983: New viruses of eukaryotic algae and protozoa. In: A Critical Appraisal of Viral Taxonomy. R.E.F. Matthews, ed. CRC Press, Boca Raton, FL, 177-188.

Ducklow, H.W., D.A. Purdie. P.J.L. Williams and J.M. Davies, 1986: Bacterioplankton: a sink for carbon in a coastal marine plankton community. Science, 232, 865-867.

Dundas, I., G. Bratbak and M. Heldal, 1992: Role of virus/phage in marine microbial ecosystems. In: International Marine Biotechnology Conference "IMBC. 91": Short Communications of the Invited Lectures Ecology. C.C. Nash II. ed. Developments in Microbiology Series, W. Brown, Dubuque, Iowa, 146-152.

Ferguson. R.L., E.N. Buckley and A.V. Palumbo, 1984: Response of marine bacterioplankton to differential filtration and confinement. Appl. Environ. Microbiol. 47. $49-55$.

Frank, H. and K. Moebus, 1987: An electron microscopic study of bacteriophages from marine waters. Helgol. Meeresunters., 41, 385-414.

Fuhrman, J.A., 1992: Bacterioplankton roles in cycling of organic matter: the microbial food web. In: Primary Productivity and Biogeochemical Cycles in the Sea. P.G. Falkowski and A.D. Woodhead, eds. Plenum Press, New York, 361-383.

Gerba, C.P. and G.E. Schaiberger, 1975: Effect of particulates on virus survival in seawater. J. Water Pollut. Control Fed., 47, 93-103.

Gieskes, W.W.C. and M. Elbrachter, 1986: Abundance of nanoplankton-size chlorophyll-containing particles caused by diatom disruption in surface waters of the southern ocean (Antarctic Peninsula region). Neth. J. Sea Res., 20, 291-303.

Gonzalez, J.M. and C.A. Suttle, 1993: Grazing by marine nanoflagellates on viruses and virus-sized particles: ingestion and digestion. Mar. Ecol. Prog. Ser., 94, 1-10.

Hara, S., K. Terauchi and I. Koike, 1991: Abundance of viruses in marine waters: assessment by epifluorescence and transmission electron microscopy. Appl. Environ. Microbiol., 57, 2731-2734.

Heldal, M., and G. Bratbak, 1991: Production and decay of viruses in aquatic environments. Mar. Ecol. Prog. Ser. 72. 205-212.

Hidaka, T., 1971: Isolation of marine bacteriophages from sea water. Bull. Jpn. Soc. Sci. Fish., 37, 1199-1206. , 1977: Detection and isolation of marine bacteriophage systems in the southwestern part of the Pacific Ocean. Mem. Fac. Fish. Kagoshima Univ., 20, 55-62. and T. Fujimura, 1971: A morphological study of marine bacteriophages. Mem. Fac. Fish. Kagoshima Univ., 20, 141-154.

Hutchinson, G.E., 1961: The paradox of the plankton. Am. Nat., 45, 137-145.

Joint, I.R., and A.J. Pomroy, 1983: Production of picoplankton and small nanoplankton in the Celtic Sea. Mar. Biol., 77, $19-27$.

Kapuscinski, R.B. and R. Mitchell, 1980: Processes controlling virus inactivation in coastal waters. Water Res.. 14. 363-371.

Kokjohn. T.A., G.S. Sayler and R.V. Miller, 1991: Attachment and replication of Pseudomonas aeruginosa bacteriophages under conditions simulating aquatic environments. J. Gen. Microbiol., 137, 661-666.

Kriss. A.E. and E.A. Rukina, 1947: Bacteriophages in the sea. Dokl. Akad. Nauk. SSSR, 57, 833-836.

Leach. J.E., K.W. Lee, R.L. Benson and E.L. Martin. 1980:
Ultrastructure of the infection cycle of cyanophage SM2 in Synechococcus elongatus (Cyanophyceae). J. Phycol., 16, 307-310.

Lee, S.H. and J.A. Fuhrman, 1991: Species composition shift of confined bacterioplankton studied at the level of community DNA. Mar. Ecol. Prog. Ser., 79, 195-201.

Lenski, R.E., 1988: Dynamics of interactions between bacteria and virulent bacteriophage. Adv. Microb. Ecol., 10, $1-43$.

Li, W.K.W., Subba Rao, D.V., Harrison, W.G., Smith, J.C., Cullen, J.J.. Irwin. B. and Platt, T. 1983: Autotrophic picoplankton in the tropical ocean. Science, 219, 292-295.

Mayer, J.A. and F.J.R. Taylor, 1979: A virus which lyses the marine nanoflagellate Micromonas pusilla. Nature, 28I, 299-301

McManus, G.B. and J.A. Fuhrman, 1988: Control of marine bacterioplankton populations: measurement and significance of grazing. Hydrobiologia, 159, 51-62.

Mitchell, R., 1971: Destruction of bacteria and viruses in seawater. J. Sanit. Eng. Div.. Am. Soc. Civ. Engineer., 97, 425-432.

Moebus, K., 1987: Ecology of marine bacteriophages. In: Phage Ecology. S.M. Goyal. C. Gerba and G. Bitton, eds. Wiley, New York, 137-156.

1992a: Laboratory investigations on the survival of marine bacteriophages in raw and treated seawater. $\mathrm{Hel}$ golander. Meeresunters., 46, 251-273.

1992b: Further investigations on the concentrations of marine bacteriophages in the water around Helgoland, with reference to the phage-host systems encountered. Helgolander. Meeresunters., 46, 275-292.

and H. Nattkemper, 1981: Bacteriophage sensitivity patterns among bacteria isolated from marine waters. Helgolander Meeresunters., 34, 375-385.

and H. Nattkemper, 1983: Taxonomic investigations of bacteriophage sensitive bacteria isolated from marine waters. Helgolander Meeresunters., 36, 357-373.

Murray. A.G. and G.A. Jackson, 1992: Viral dynamics: a model of the effects of size, shape, motion and abundance of single-celled planktonic organisms and other particles. Mar. Ecol. Prog. Ser., 89, 103-116.

Pace, M.L. 1988: Bacterial mortality and the fate of bacterial production. Hydrobiologia, 159, 41-49.

Padan, E. and M. Shilo, 1973: Cyanophages-viruses attacking blue-green algae. Bacteriol. Rev., 37, 343-370.

Paul, J.H., S.C. Jiang and J.B. Rose, 1991: Concentration of viruses and dissolved DNA from aquatic environments by vortex flow filtration. Appl. Environ. Microbiol., 57, 2197-2204

Peduzzi, P., J.B. Rose, S.C. Jiang. C.A. Kellogg and L. Dickson, 1993: Distribution of viral abundance in the reef environment of Key Largo, Florida. Appl. Environ. Microbiol., 59, 718-724.

Pienaar, R.N., 1976: Virus-like particles in three species of phytoplankton from San Juan Island. Washington. Phycologia, 15, 185-190.

Proctor, L., 1991: Marine viruses and the fate of bacteria in the ocean. Ph.D. thesis, State University of New York at Stony Brook.

and J.A. Fuhrman, 1990: Viral mortality of marine bacteria and cyanobacteria. Nature, 343, 60-62.

and J.A. Fuhrman, 1991: Roles of viral infection in organic particle flux. Mar. Ecol. Prog. Ser. 69. 133-142.

and J.A. Fuhrman, 1992: Mortality of marine bacteria in response to enrichments of the virus size fraction from seawater. Mar. Ecol. Prog. Ser, 87, 283-293.

, J.A. Fuhrman and M.C. Ledbetter, 1988: Marine bacteriophages and bacterial mortality. EOS Trans. Am. Geophys. Union, 69, 1111-1112.

, A. Okubo and J.A. Fuhrman, 1993: Calibrating estimates of phage-induced mortality in marine bacteria: 
ultrastructural studies of marine bacteriophage development from one-step growth experiments. Microb. Ecol., $25,161-182$.

Safferman, R.S. and M.E. Morris, 1963: Algal virus: isolation. Science, 140, 679-680.

and M.E. Morris, 1967: Observations on the occurrence, distribution and seasonal incidence of blue-green algal viruses. Appl. Microbiol., 15, 1219-1222.

Servais, P., G. Billen and J.V. Rego, 1985: Rate of bacterial mortality in aquatic environments. Appl. Environ. Microbiol. 49, 1448-1454.

Sharp, G.D., 1949: Enumeration of virus particles by electron microscopy. Proc. Soc. Exp. Biol. Med., 70, 54-59.

Sherr. B.F., E.B. Sherr and C. Pedros-Alio, 1989: Simultaneous measurement of bacterioplankton production and protozoan bacterivory in estuarine water. Mar. Ecol. Prog. Ser., 54, 209-219.

Sherr, E.B., B.F. Sherr and L.J. Albright, 1987: Bacteria: Link or sink? Science, 235, 88.

Shuval. H.I., A. Thompson, B. Fattal, S. Cymbalista and Y. Wiener, 1971: Natural virus inactivation processes in seawater. J. Sanit. Eng. Div., Am. Soc. Civ. Engineer., 97, 587-600.

Sieburth, J.M., 1979: Sea Microbes., Oxford University Press, New York. 489 pp.

, P.W. Johnson and P.E. Hargraves, 1988: Ultrastructure and ecology of Aureococcus anophagefferens gen. et sp. nov. (Chrysophyseae): the dominant picoplankter during a bloom in Narragansett Bay, Rhode Island, Summer 1985. J. Physol., 24, 416-425.

Sindermann, C.J., 1990: Principle diseases of marine fish and shellfish. Academic, vol. 2, New York, 516 pp.

Smith, D.C., M. Simon, A.L. Alldredge and F. Azam, 1992: Intense hydrolytic enzyme activity on marine aggregates and implications for rapid particle dissolution. Nature, 359, 139-142.

Smith, E.M., C.P. Gerba and J.L. Melnick, 1978: Role of sediment in the persistence of enteroviruses in the estuarine environment. Appl. Environ. Microbiol. 35, 685-689.

Spencer. R., 1955: A marine bacteriophage. Nature, 175, 690. , 1960: Indigenous marine bacteriophages. J. Bact., $79,614$.

, 1961: Bacterial viruses in the sea. In: Symposium on Marine Microbiology, C.H. Oppenheimer, ed., C.C. Thomas, Springfield, Illinois. 350-365.

Steward, G.F., J. Wikner, D.C. Smith, W.P. Cochlan and F. Azam, 1993a. Measurement of virus production in the sea: I. Method development. Mar. Microb. Foodwebs 6:57-78.

, J. Wikner. W.P. Cochlan, D.C. Smith and F. Azam, $1993 \mathrm{~b}$. Measurement of virus production in the sea: II Field results. Mar. Microb. Foodwebs 6:79-90.

Stockner, J.G. and N.J. Antia, 1986: Algal picoplankton from marine and freshwater ecosystems: a multidisciplinary perspective. Can. J. Fish. Aquat. Sci., 43, 2472-2503.

Suttle, C.A., 1992: Inhibition of photosynthesis in phytoplankton by the submicron size fraction concentrated from seawater. Mar. Ecol. Prog. Ser., 87, 105-112.

1993: Enumeration and isolation of viruses. In: Current Methods in Aquatic Microbiology, P.F. Kemp, B.F. Sherr. E.B. Sherr and J.J. Cole, eds. Lewis Publ., Boca Raton, Florida, 121-134.

and A.M. Chan, 1993: Marine cyanophages infecting oceanic and coastal strains of Synechococcus: abundance, morphology, cross-infectivity and growth characteristics. Mar. Ecol. Prog. Ser., 92, 99-109.

, A.M. Chan and M.T. Cottrell, 1990: Infection of phytoplankton by viruses and reduction of primary productivity. Nature, 347, 467-469.

, A.M. Chan and M.T. Cottrell, 1991: Use of ultrafiltration to isolate viruses from seawater which are pathogens of marine phytoplankton. Appl. Environ. Microbiol., 57, 721-726.

and F. Chen, 1992: Mechanisms and rates of decay of marine viruses in seawater. Appl. Environ. Microbiol., 58. 3721-3729.

, F. Chen and A.M. Chan, 1992: Marine viruses: decay rates, diversity and ecological implications. pp. 153-163. In: International Marine Biotechnology Conference "IMBC-91": Short Communications of the Invited Lectures Ecology, C.C. Nash II ed. Developments in Microbiology Series, W. Brown Co., Dubuque, Iowa.

Thingstad, T.F., M. Heldal, G. Bratbak and I. Dundas, 1993: Are viruses important partners in pelagic food webs? Trends Ecol. \& Evol., 8, 209-213.

Torrella, F. and R.Y. Morita, 1979: Evidence for a high incidence of bacteriophage particles in the waters of Yaquina Bay, Oregon: Ecological and taxonomical implications. Appl. Environ. Microbiol., 37, 774-778.

Van Etten, J.L., L.C. Lane and R.H. Meints, 1991: Virus and viral-like particles of eukaryotic algae. Microbiol. Rev., 55. 586-620.

Walsh, J.J., 1983: Death in the sea: enigmatic phytoplankton losses. Prog. Oceanogr., 12, 1-86.

Waters, R.E. and A.T. Chan, 1982: Micromonas pusilla virus: The virus growth cycle and associated physiological events within the host cells; host range mutation. $J$. Gen. Virol., 63, 199-206.

Wiggins, B.A. and Alexander, M., 1985: Minimum bacterial density for bacteriophage replication: implications for significance of bacteriophages in natural ecosystems. Appl. Environ. Microbiol., 49, 19-23.

Williams, P.J. leB., 1981: Incorporation of microheterotrophic processes into the classical paradigm of the planktonic food web. Kieler Meeresforsch. Sonderh., 5, 1-28.

Wommack, K.E., R.T. Hill, M. Kessel, E. RussekCohen and R.R. Colwell, 1992: Distribution of viruses in Chesapeake Bay. Appl. Environ. Microbiol., 58, 2965-2970.

Zachary, A., 1976: Physiology and ecology of bacteriophages of the marine bacterium Beneckea natriegens: salinity. Appl. Environ. Microbiol., 31, 415-422.

, 1978: An ecological study of bacteriophages of Vibrio natiegens. Can. J. Microbiol., 24, 321-324. 